\title{
IN THE TOWER
}

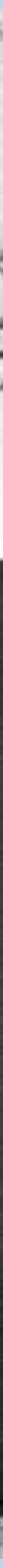




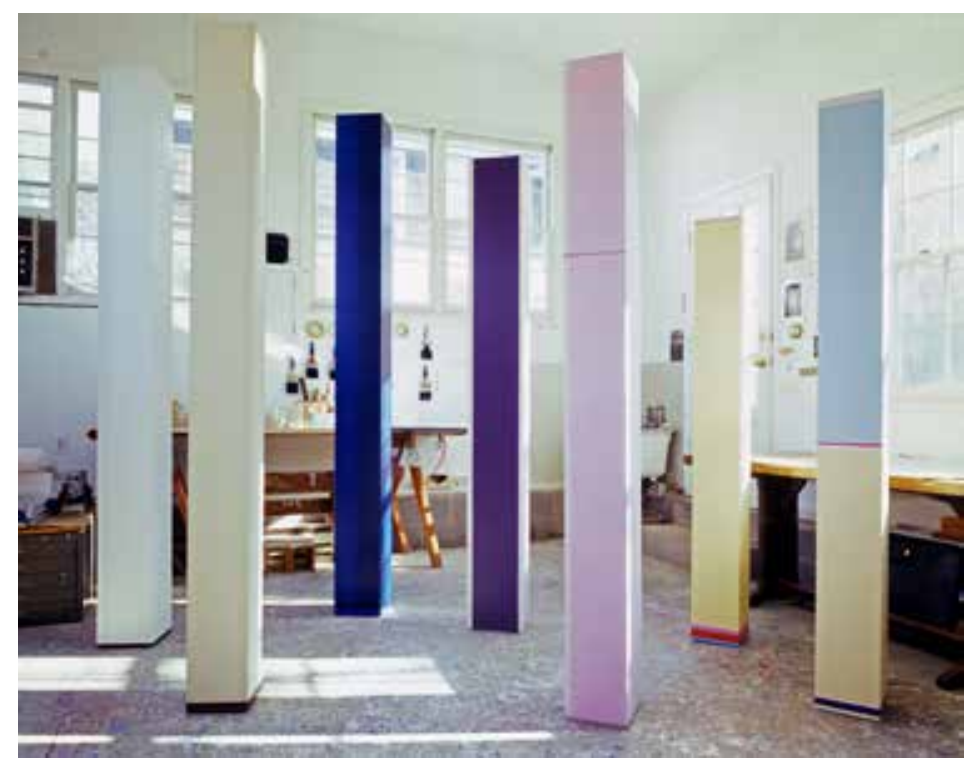

35th Street studio, 1979 (fig. 1)

Anne Truitt's house in the Washington, DC, neighborhood of Cleveland Park sat on a hill overlooking the city. A typically Mid-Atlantic dwelling of a certain vintage - shingled, with a porch and pale blue shutters - it was easy to miss. Her similarly modest studio sat behind a well-tended patch of lawn (fig. 1). She designed the studio herself with the advice of an architect, and it perfectly suited her needs. Natural light poured in through the paned windows. Brushes and rollers hung beside a sink next to the masking tape that Truitt used to create the exacting divisions of color on her works. There were flat files of drawings, Pyrex bowls for mixing colors, sawhorses and ladders that she enlisted to paint and sand her wooden armatures. Jars of acrylic paint filled three low shelves. I remember a few uncomfortable little chairs. A back door opened onto an alley through which her finished works were conveyed to their destinations.

Truitt's studio was not a place for dilettantish pleasures, or "dithering," as she would say. It was a place to work. It was here, in 1997, that we began a series of conversations that ended only with her death seven years later. A small portion of those exchanges appears below.

The Cleveland Park studio was Truitt's final workspace in Washington, the city that served as her base of operation from 1960 until her death in 2004, with the exception of her sojourn in Tokyo from 1964 to 1967 . Before living abroad she rented a room in a boarding house conveniently located across the street from her home on 3oth Street NW in Georgetown. The small room provided the artist a place where she could work early in the morning before bringing her children to school. It was here that she built her inaugural mature sculpture, First, and completed an extraordinary sequence of drawings culminating in the black and violet acrylic works on paper (figs. 2 and 3). She also maintained a studio in a former carriage house in Twining Court, an alley near Dupont Circle. Although unheated and infested with rats, the Twining Court studio was spacious enough for Truitt to build her early large sculptures, including the towering Insurrection and the wall-like Knight's Heritage featured in this exhibition (figs. 4 and 5). After her return from Japan Truitt worked in a studio on Tilden Street, then in a brick row house on Calvert Street in the Adams Morgan neighborhood. She built the Cleveland Park studio with a portion of the funds from a Guggenheim Fellowship in 1971, and worked periodically in a studio at Yaddo, an artists' colony near Saratoga, New York, beginning in 1974. Each of these workspaces afforded a different scale, a different light, a different ambience.

They were places where a wife and mother could develop her professional identity as an artist places she could call her own. 


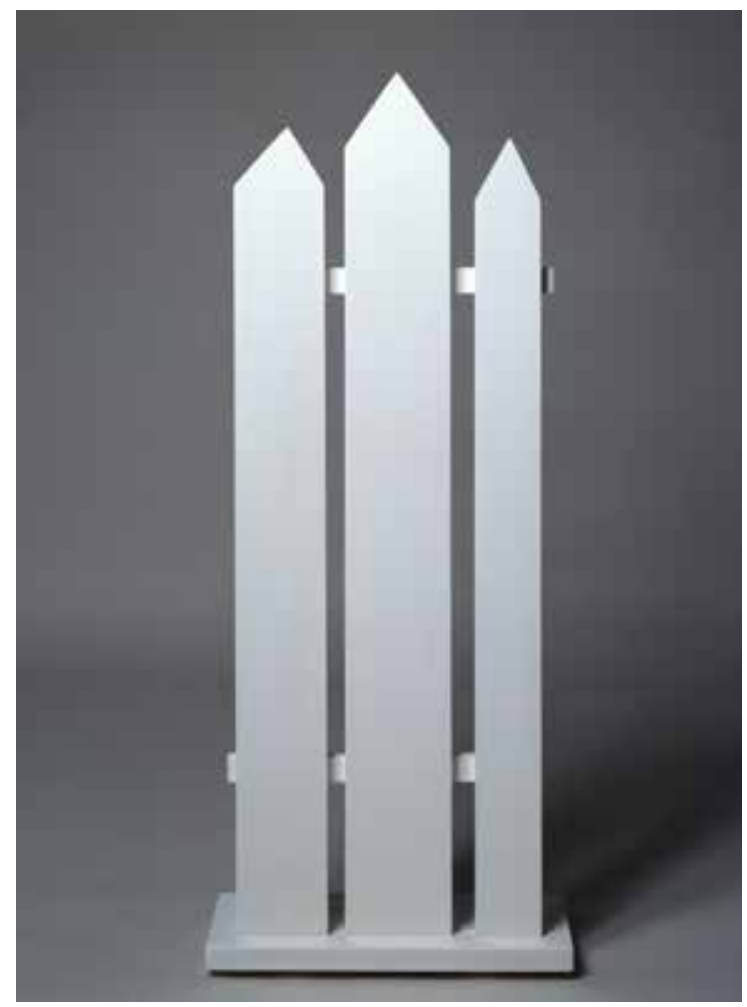

First, 1961 (fig. 2)

Truitt disliked being called a "woman artist" as much as she disliked being known as a "minimalist," even though her 1963 debut at André Emmerich Gallery in New York was arguably the first solo show of minimal-type sculpture. Such identifications reduced her work and its interpretation, and her expansive sense of self. The sexism of the 1960s art world "couldn't be exaggerated," she remarked to me. And as she told the Washington Post in 1987, "I have never allowed myself, in my hearing, to be called a minimalist." Certainly, none of the so-called minimalists liked this label, which implied that their works offered too little to look at and evinced insufficient artistic labor. But even as Truitt put seemingly simple geometric shapes directly on the floor, she insisted on painting her works by hand and choosing colors intuitively. (In contrast, Donald Judd, for instance, enlisted workshops to make his geometric sculptures and factory-dyed Plexiglas.) Her titles as well as her palette, which included pinks, daisy yellows, and other hues denigrated as frivolous or "feminine," were evocative and daring during a period when feeling and reference were largely banished from abstract art, and when many artists left their works untitled and favored "neutral" tones (figs. 6 and 7).

Being known as a "Washington artist" was a problem, too. It tethered Truitt to the Washington Color School artists, among whom she counted such colleagues as Kenneth Noland (she inherited the Twining Court studio from him), Morris Louis, and her close friend Mary Pinchot Meyer, the inspiration for the sculpture Mary's Light. Unlike these painters, Truitt developed an art that is insistently sculptural, that we experience in three dimensions, not two. "Washington" also meant "local." It meant that she would not achieve the fame of Louise Bourgeois or Helen Frankenthaler, who "stayed on the scene" in New York, Truitt told me, and were "right" to do so.

So why did she stay? Born in Baltimore in 1921 and raised on Maryland's Eastern Shore, Truitt - who often spoke of how human beings, like sailors, are bound to the latitude and longitude of the earth - chose to remain in her native habitat. (Below, she praises the "wonderful" light of the Chesapeake region.) 


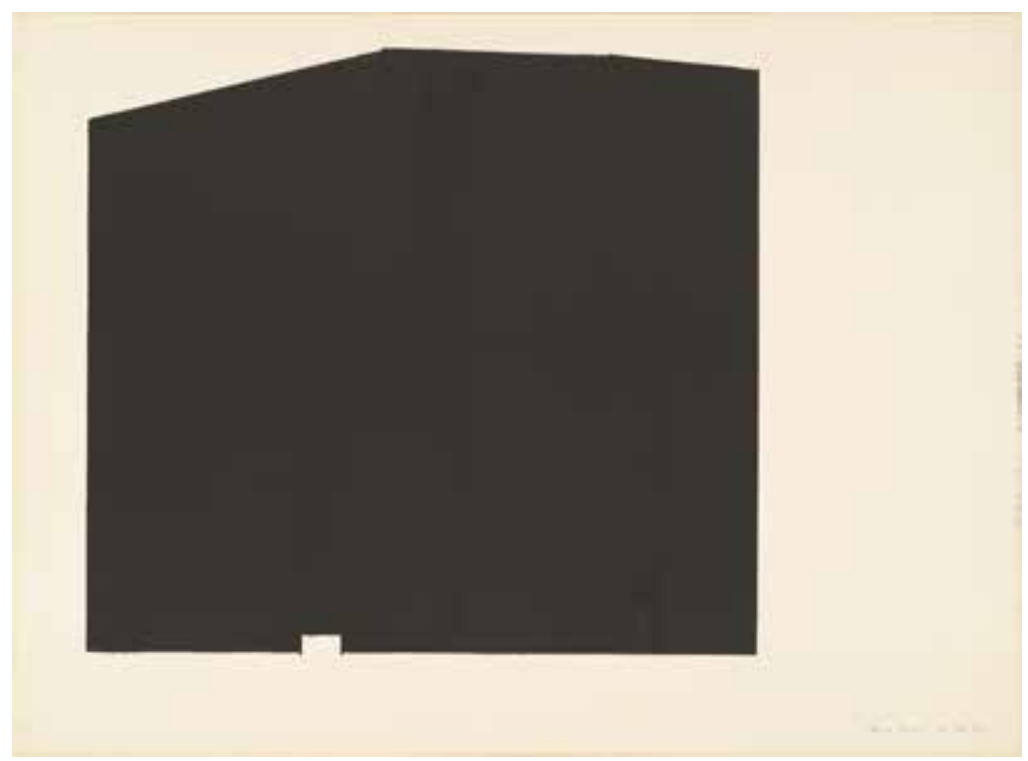

26 December 1962, No. 5, 1962 (fig. 3)

Her observation that her work "depends on my being quiet" is also telling. In Washington, far from the clamor of the New York art world, she maintained a life in the studio, a studio existence. She was able to proceed quietly, away from the prying eyes of collectors and competitors. She could focus on the works that "appeared" in her mind, as she put it - works that demanded to be made. She could disappear into her backyard studio, shut the door, and work.

\section{JAMES MEYER: Your debut show at André} Emmerich, in 1963, was one of the first exhibitions of large-scale geometric sculpture. How did you come to make some of the earliest "minimal" art?

ANNE TRUITT: The question implies that I did it on purpose, which is not true. What happened is that I began to see how I could make exactly what I wanted to make in a new way. It was a complete volte-face from my previous work. At the time I was making life-size figures of steel pipes with chicken wire and plastic and cloth. They were gothic figures and sort of bestial; I was also making casts of clay heads in very dark, colored cement, very ugly and very primitive. They had nothing to do with art, in a way; they had to do with self-expression. In November 1961 I began to make the things I am making now.
JM: It all began with First, that modest little sculpture in the Baltimore Museum that resembles, but isn't, a white picket fence.

AT: It went in a rather literal progression. I did First, which is a perfectly straight picket fence that I put together myself. And then I did Southern Elegy, which is a perfectly straight tombstone structure, and then Two, and made a jump: I realized that changes in color induced, or implied, changes in shape. That though color and structure retained individuality, they could join forces rather as independent melodies can combine into a harmonic whole. And that when I combined them in a particular way, they had a particular content - particular to me, that is, a meaning that was important to me. Once it had occurred to me that I could use color metaphorically for content, I realized that I could go ahead with new freedom. What I was doing dawned on me as the works got bigger: strange-looking objects that just stood there in the studio for almost a year, where no one came but me.

\section{$J M:$ Why were you dissatisfied with the figura-} tive work?

AT: It was nowhere near broad or wide or deep or open enough. With abstraction you can go as far as you can go. But with the figure you are stuck because you're dealing with actuality. 


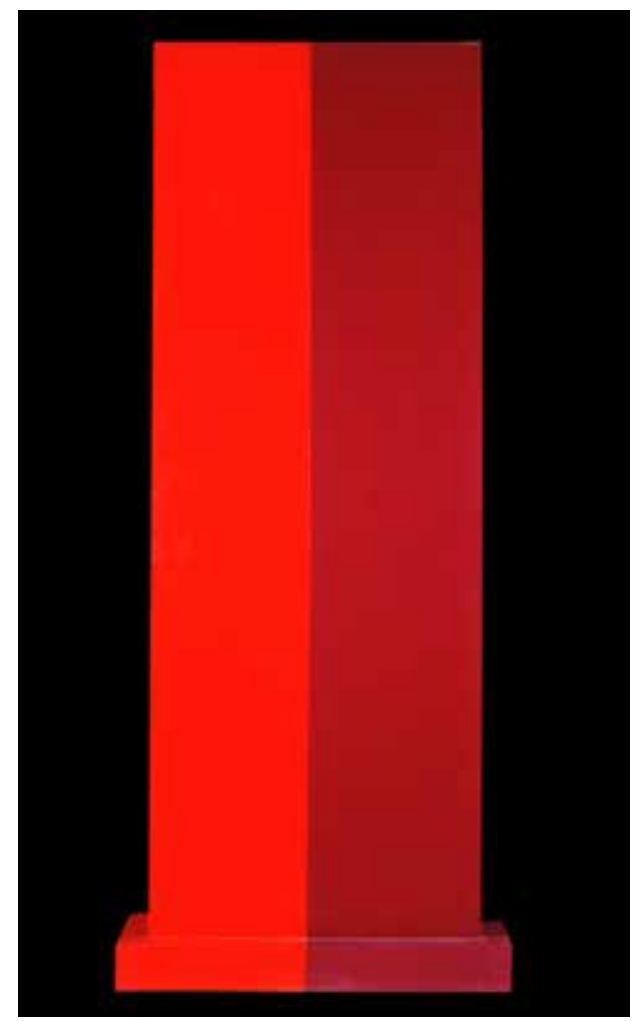

Insurrection, 1962 (fig. 4)

JM: What was it about these simple shapes and fields of color that was going to be the language of your work?

AT: I'm sorry, I just don't think that way. It's as if you're asking me to put the cart in front of the horse when I have neither horse nor cart. I just thought, I must make these things.

\section{$J M$ : But why this form and that color to express a particular content?}

AT: I never thought about it. The objects came in with their intrinsic subject matter - like baseballs thrown on a curve. I don't know how to put it into words.

JM: Well, I'm suggesting the forms you used weren't arbitrary. Your early work is mostly large, bulky shapes.

AT: I think you'd have to say that what l've been about is being alone in the world, looking around at it, and trying to absorb it, at first with extremely nearsighted eyes. I didn't see a damn thing until
I was in fifth grade. Nobody knew I couldn't see. So when you talk about the big things that I made, I think what it may have been is this person going around through the world, either on her legs or on her bicycle, in a place confettied by large, anonymous structures - just big blocks of white or gray. I couldn't see anything except these big blocks. And I had to go on smell and sound.

\section{JM: And tactility.}

AT: And tactility. It's sort of a frightening way to grow up. I wandered around in a daze.

JM: Most of the artists who came to be called minimalists purged their work of metaphor or subject matter. In your work, the form was generated by the artist herself in order to contend with a particular subject matter.

AT: My idea was not to get rid of life but to keep it and to see what it is. But the only way I seem to be able to see what anything is, is to make it in another form, in the form in which it appears in my head. Then when I get it made I can look at it. 


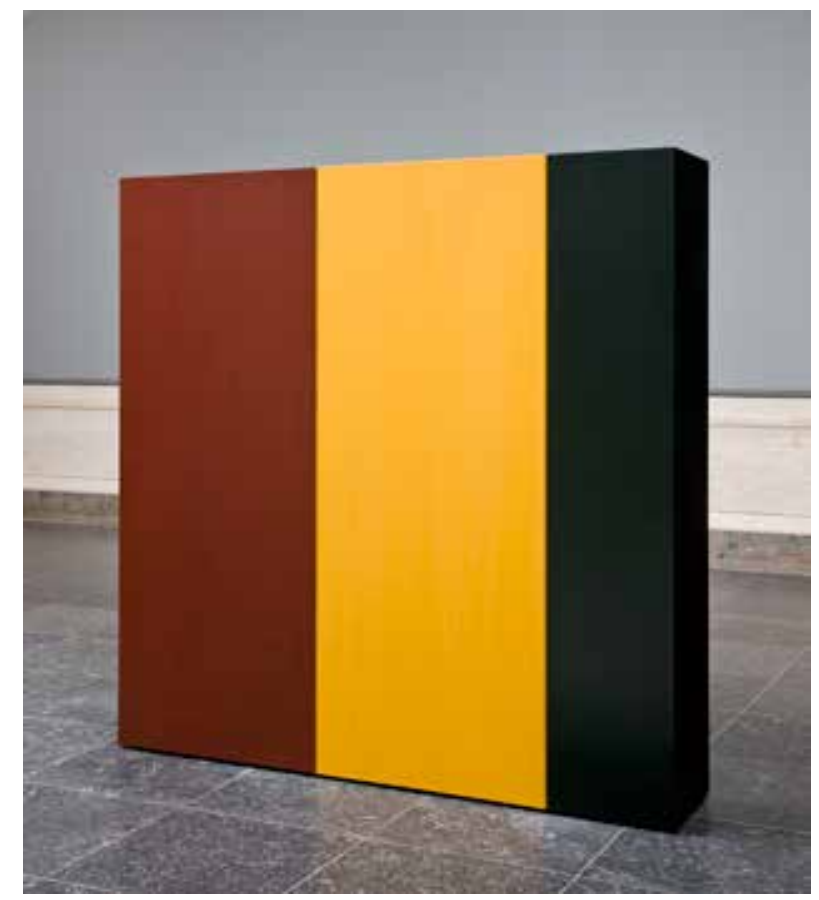

Knight's Heritage, 1963 (fig. 5)

JM: When you had your first exhibition, at Emmerich, the work must have looked far out and strange.

AT: It was a strange distillation of a person's life. The works were not devised and they were not art. I didn't make them out of art. I've never understood people who made art out of art.

\section{JM: What do you mean by "art"?}

AT: You know. Something devised, something where people live to express themselves. I did that for twelve years - worked and worked to make something on the outside that met and matched my inside.

JM: But I thought your work was expressive. You've mentioned that Hardcastle - one of your largest works, a tall black wall held up by red struts - alludes to a man who was run over by a train not far from your parents' summer home. It was a horrible event from your childhood.

AT: No. This was about trying to objectify my life. It wasn't about me myself. That was the whole virtue of it.
JM: How did Clement Greenberg, the leading critic of the era, come to see your work? Was it through Kenneth Noland?

AT: Yes. First it was Ken, who told David Smith. David was the biggest, strongest supporter anybody could ever have.

JM: So they were the first two people to see your work?

AT: Yes; and then Clem. Clem said, "Now there will be three in Washington."

JM: You, Noland, and Morris Louis, presumably. Greenberg talks about how difficult your work was for him initially, how he had to go back again until he finally "saw" it. Yet you've said he was impressed right away.

AT: Right away. There was no question about it.

JM: You became marked as "Greenberg's minimalist." He characterizes your work as a welcome antidote to that of Judd, Robert Morris, and Carl Andre. He praises the handmade quality of your sculpture and its intuitive color and attacks the industrial look of "orthodox" 
minimalism. But you've also said that you later felt Greenberg was disappointed in you.

AT: He was not supportive all the way through; he was polite. I think he was disappointed - angry in a way - maybe because I didn't do what he thought I should do. Perhaps he thought that I should pay attention to him and ask him what to do. I'm not quite sure what he wanted. But he didn't want what I did - which was never to ask him any questions at all, never to ask his opinion, and to go my own way. Maybe what Clem wanted me to do was to stay safe within the language of sculpture, to retain sculptural checks and balances. Actually I just lost interest in that language after 1961. And now my sculptures pivot on the invisible line of gravity that holds them to the ground. I just got simpler.

JM: More "minimal," which he didn't like. He said that your work flirted with the look of “non-art," like Judd's.

AT: No, he didn't entirely like it. Maybe he thought I should use color in a cubist fashion, should fit my work into that art-historical imperative.

JM: Like David Smith or Anthony Caro, whose welding and balancing of parts he traced straight to Picasso: a perfect modernist narrative.

AT: I said to myself, I'm not going to do it. And I just stayed down here in Washington and kept on working.

JM: You've described the first show as a success. How so?

AT: I guess in terms of comment. At the time Clem was really dominating things, and Ken was powerful. Helen Frankenthaler came to see my work and traded. There were all these people in this world around André Emmerich.

JM: And they were all at their height.

AT: It was the apogee for them. February '63, that was it, you know. There was nobody else around.

JM: Pop was just taking off, yet Greenberg was still calling the shots.
AT: Even I could see that I was at the center of a power game.

JM: Greenberg made you one of "his" artists. What was it like to put up a show with him?

AT: Let me go back to February 1963, with these three men - Bill Rubin, Clem, and Ken - arranging the stuff in André's gallery. I was completely floored. I had never thought of the works together. I had simply thought of them as individual sculptures. I was astonished to see how they considered them in relation to one another. And they put two of them in the back room because they didn't "fit."

JM: So they installed your show. Did you agree with their choices?

AT: Well, for once in my life I was feeling rather passive. I was very conscious of being a neophyte. And they were very powerful; they were men in their own world.

JM: Much has been said about what an uphill battle women artists faced in the '6os. One looks at figures like you and Agnes Martin as something like survivors. Are the claims of sexism overrated or exaggerated?

AT: Underrated. Couldn't be exaggerated.

$J M$ : Yet your shows got reviewed in all of the magazines and by major critics. You've shown consistently for over forty years.

AT: I know, it's incredible.

JM: And yet you've told me that Greenberg and André Emmerich were disappointed that you never "took off" sufficiently. You didn't work your career.

AT: I never claimed my place. Louise Bourgeois stayed on the scene. She claimed her place day and night, year in and year out, and she has it and she should have it. Louise Nevelson claimed her place and stayed there and fought for it. Frankenthaler, too.

JM: Does your reserve on this score have anything to do with being a woman? 


$$
1
$$




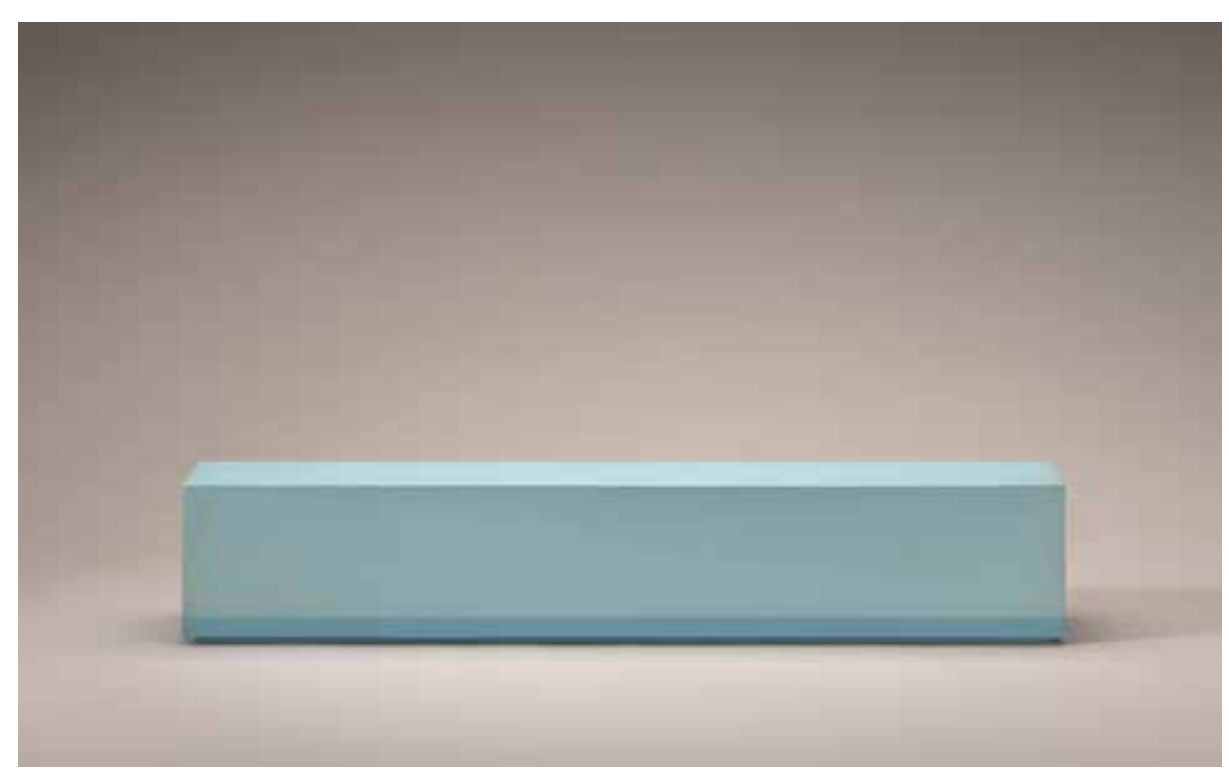

Parva XII, 1977 (fig. 7)

AT: Let's say that had I been a man, I would have been an equal. Also, I had been brought up never to call attention to myself.

JM: The successful women artists of your generation, we can count on one hand.

AT: We didn't even finish a hand. It isn't that these artists made a great big ruckus - they just stayed in situ. I think they were right. There's nothing wrong with it. But my character and my work are very quiet. My work depends on my being quiet. Psychologically, I can't afford that kind of public attention. I don't have the temperament for it.

$J M$ : You've lived quietly in Washington all of these years. Why did you stay?

AT: The light is wonderful in Washington. And I have a lifetime of friends here. It's the latitude and longitude I was born on.

JM: There's another aspect to your life here. Being in Washington may be unhelpful for a career in the art world but is so interesting in terms of the real world. You were one of the inhabitants of Camelot. Your then husband, James Truitt, was high up at the Washington Post and Newsweek during the Kennedy administration.
AT: Well, I was tangential to the "corridors of power," if that's what you mean. For someone who is as simple a person as I, I've led a sort of melodramatic life. It was my husband who pulled me into it, of course.

JM: People often try to connect the artist's life and work in obvious ways: They refract the art through the lens of biography. I can already see a reading that goes like this: "Truitt, living in Washington at the height of the Cold War"-

AT: I'm just agog with interest at what you're going to say -

JM: - "devised an abstraction that sought to escape, and yet expressed, US imperialist power." I'm thinking of the old reading of abstract expressionism's manipulation by the US Information Agency to represent an American ideology of "freedom."

\section{AT: That's true.}

JM: Yet the artists who lived in New York were far removed from power. Newman and Rothko were children of immigrants; they lived modestly. But you're in Washington in Georgetown - during the Cold War. And you're keeping one studio across the street and another in Twining Court. 


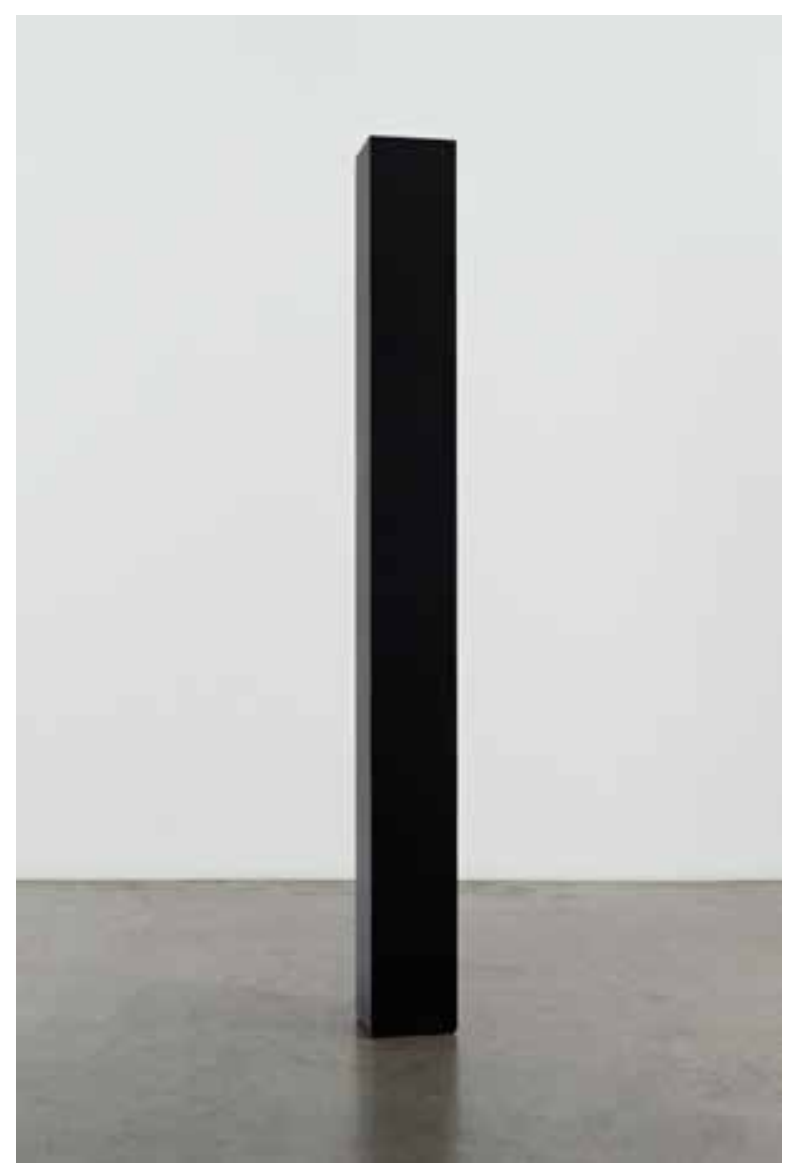

Twining Court II, 2002 (fig. 8)

AT: I worked in between carpools and buying food and cooking and whatever else I had to do. I lived an outside life, but really I was living an inside life.

JM: Yet you were a personal friend of the people running the country. A lot of your friends were in the $\mathrm{CIA}$.

AT: I've always thought it was peculiar, too. I was floating around in that world...I didn't pay attention to what was going on. And remember, much was secret. People were covert. It was interesting, really, looking back on it. But my private feelings about it were that it was just very strange. I don't understand why fate led me to be in such a situation.

JM: There doesn't seem to be a clear-cut relation between your work and that situation - which doesn't mean there isn't one.
AT: I don't really see it. But that's exactly the way it was.

\section{JM: You turned eighty last year. Has age, in some way, affected your work? (fig. 8)}

AT: I don't think age makes any difference except that it endows a person with freedom. Age cuts you off, untethers you. It's a great feeling. The other thing is, when you get to be eighty, you're looking back and down, out from a peak. I can look down and see my life from my own little hill; I see this plain, all the years of experience.

\section{JM: Does that mean making the work is some-} how easier?

AT: No, it's harder. It costs me much more; I have all those years that I have to face and it takes a certain amount of courage. It's not a light and foolish thing. Color is getting more complex and harder and harder to mix. There are more com- 
plexities in it because my own experience is much more complex.

\section{JM: Is it physically more difficult to work?}

AT: It's not more difficult to be faithful, but I have to be faithful to more and more. And I have less psychic energy as I get older. Heaven knows I have less physical energy!

\section{JM: But it has not changed the fundamental} process or ambition of the work. If anything, the ambition has increased.

AT: Yes, I would say, by leaps and bounds.

JM: And the laborious process you use - painting the wood support in layer after layer of crosshatched color - hasn't changed. What happens if you're not pleased with the result?

AT: I take the color off and begin again.

\section{JM: All the color? The white undercoats?}

AT: Take them all off. Go back to the wood and come forth again. You never make the same mistake twice. Next time I will have learned.

\section{JM: How do you get rid of the twenty or so coats?}

AT: It's a horrible job. You have to wear a mask and rubber gloves and use newspaper and paint remover to take off all the paint. And sand.

\section{JM: To the bare wood.}

AT: It's a patient business. Sometimes you can be on that very last coat and it'll go wrong. All of a sudden it just won't do anymore: My hand goes out. So it's always a question of attention, of waiting.

\section{JM: Do you put the sculpture away?}

AT: I take the color off it and begin again. Or I go in the house and wait. Or I move on to another sculpture and look at it out of the corner of my eye. At a certain point l'll go back to it. I don't exactly fix it. I just pick up where I am.

\section{$J M:$ And when the sculpture's ready?}

AT: It's over. The whole thing is over as far as I'm concerned. Then I have to take care of the object itself. The reward is the making. I think all artists would agree with that.

This interview is adapted from a previous publication, (c) Artforum, May 2002, "Grand Allusion: James Meyer Talks with Anne Truitt.”

\section{EXHIBITION CHECKLIST}

\section{Gallery 1}

Insurrection, 1962, acrylic on wood, $255.27 \times 106.68 \times$ $40.64 \mathrm{~cm}(1001 / 2 \times 42 \times 16$ in.), National Gallery of Art, Washington, Corcoran Collection (Gift of Mr. and Mrs. Phillip Stern) (fig. 4)

Mary's Light, 1962, acrylic on wood, $135.89 \times 38.1 \times 17.78 \mathrm{~cm}$ $\left(53 \frac{1}{2} \times 15 \times 7\right.$ in.), Angleton/Khalsa Family

Knight's Heritage, 1963, acrylic on wood, $153.35 \times 153.35 \times$ $30.48 \mathrm{~cm}(603 / 8 \times 603 / 8 \times 12$ in.), National Gallery of Art, Washington, Gift of the Collectors Committee (fig. 5)

Flower, 1969, acrylic on wood, $217.17 \times 45.72 \times 45.72 \mathrm{~cm}$ $\left(85^{1 / 2} \times 18 \times 18 \mathrm{in}\right.$.), National Gallery of Art, Washington, Corcoran Collection (Museum Purchase)

Mid Day, 1972, acrylic on wood, $305.3 \times 65 \times 34.4 \mathrm{~cm}$ (120 $3 / 16 \times 25 \% / 16 \times 13 \%$ in.), National Gallery of Art, Washington, Gift of Harry and Margery Kahn

Spume, 1972, acrylic on wood, $305 \times 64.9 \times 34.4 \mathrm{~cm}$ $(120 \% 116 \times 25 \% 16 \times 13 \%$ in.), National Gallery of Art, Washington, Gift of friends of Anne Truitt

Sand Morning, 1973, acrylic on canvas, $54.61 \times 105.41 \mathrm{~cm}$ (21 1/2 $\times 41 \frac{1}{2}$ in.), National Gallery of Art, Washington, Gift of Robert and Mercedes Eichholz

Arundel XI, 1974, graphite and acrylic on canvas, $186.69 \times$ $186.69 \mathrm{~cm}\left(73 \frac{1}{2} \times 73^{1 / 2}\right.$ in.), National Gallery of Art, Washington, Corcoran Collection (Museum Purchase with the aid of funds from the National Endowment for the Arts, the William A. Clark Fund, and Margaret M. Hitchcock) 
Parva XII, 1977, acrylic on wood, $14.61 \times 81.28 \times 10.16 \mathrm{~cm}$ ( $5 \% 3 \times 32 \times 4$ in.), National Gallery of Art, Washington, Gift of Margot Wells Backas (fig. 7)

Summer Remembered, 1981, acrylic on wood, $208.28 \times 20.32 \times$ $20.32 \mathrm{~cm}(82 \times 8 \times 8$ in.), National Gallery of Art, Washington, Gift of Carolyn Small Alper (fig. 6)

Twining Court II, 2002, acrylic on wood, $205.74 \times 20.32 \times$ $20.32 \mathrm{~cm}$ (81 × $8 \times 8$ in.), John and Mary Pappajohn.

(fig. 8)

\section{Gallery 2}

Dutchman's Lane, 1961 - 1962, graphite on paper, $20.32 \times$ $12.7 \mathrm{~cm}$ ( $8 \times 5$ in.), Estate of Anne Truitt, Courtesy Matthew Marks Gallery

Dutchman's Lane, 1961 - 1962, graphite on paper, $20.32 \times$ $12.7 \mathrm{~cm}$ ( $8 \times 5$ in.), Estate of Anne Truitt, Courtesy Matthew Marks Gallery

Structures/Buildings, Easton, Maryland, 1961 - 1962, graphite on paper, $21.59 \times 35.56 \mathrm{~cm}(81 / 2 \times 14$ in. $)$, Estate of Anne Truitt, Courtesy Matthew Marks Gallery

21 Nov '62, 1962, graphite on paper, $76.2 \times 55.88 \mathrm{~cm}(30 \times 22$ in.), Estate of Anne Truitt, Courtesy Matthew Marks Gallery

26 December 1962, No. 1, 1962, acrylic on heavy wove paper, $55.88 \times 76.2 \mathrm{~cm}$ (22 × 30 in.), National Gallery of Art, Washington, Corcoran Collection (Museum Purchase with the aid of funds from the National Endowment for the Arts and the William A. Clark Fund)

26 December 1962, No. 5, 1962, acrylic on heavy wove paper, $55.88 \times 76.2 \mathrm{~cm}$ ( $22 \times 30$ in.), National Gallery of Art, Washington, Corcoran Collection (Gift of the artist in memory of Gene Baro) (fig. 3)

Working Drawing, 1962, acrylic and graphite on paper, 27.94 $\times 61.91 \mathrm{~cm}(11 \times 24$ 3/8 in.), Estate of Anne Truitt, Courtesy Matthew Marks Gallery

Truitt '66 [4], 1966, acrylic on paper, $52.71 \times 69.85 \mathrm{~cm}$ (20 $3 / 4 \times 27 \frac{1}{2}$ in.), Estate of Anne Truitt, Courtesy Matthew Marks Gallery

20 Feb '68, 1968, acrylic on paper, $34.29 \times 103.51 \mathrm{~cm}$ $\left(13 \frac{1 / 2}{2} \times 40^{3 / 4}\right.$ in.), Collection of Mary H. Davidson Swift
Untitled, 1968, acrylic on paper, $29.4 \times 104.3 \mathrm{~cm}(11 \% / 16 \times$

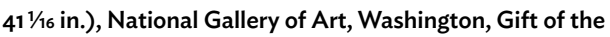
Woodward Foundation, Washington, DC

24 Oct ' 71,1971 , acrylic on paper, $50.8 \times 76.2 \mathrm{~cm}(20 \times 30 \mathrm{in}$.$) ,$ Collection of Mary H. Davidson Swift

1 June 1976, 1976, acrylic with graphite on paperboard, $55.88 \times 76.36 \mathrm{~cm}(22 \times 301 / 16$ in. $)$, National Gallery of Art, Washington, Corcoran Collection (Exchange and gift of Ramon Osuna)

Anne Truitt, Working, a film directed by Jem Cohen, 2009, 13 minutes, $16 \mathrm{~mm}$

Anne Truitt artwork (c) annetruitt.org/Bridgeman Images

Anne Truitt in Twining Court studio, 1962. (C) annetruitt.org/ Bridgeman Images (cover)

Anne Truitt's 35th Street studio, 1979. (C) annetruitt.org/ Bridgeman Images (fig. 1)

Anne Truitt, First, 1961, acrylic on wood, Baltimore Museum of Art. (C) annetruitt.org/ Bridgeman Images (fig. 2)

Anne Truitt, Insurrection, 1962. (C) annetruitt.org/Bridgeman Images (fig. 4)

Anne Truitt, Twining Court II, 2002. (C) annetruitt.org/Bridgeman Images (fig. 8)

Brochure produced by the department of exhibition programs and the publishing office, National Gallery of Art. (C) 2017 Board of Trustees, National Gallery of Art, Washington

The exhibition is organized by the National Gallery of Art.

The exhibition is made possible through the generous support of the Robert and Mercedes Eichholz Foundation.

Additional funding is provided

by The Tower Project of the National Gallery of Art and Steven Elmendorf. 